\title{
我国建筑业农民工权益保障问题分析
}

杨泽峰

山西焦煤集团房地产开发有限公司

DOI:10.32629/ems.v1i2.371

[摘要] 伴随着近年来我国社会经济的快速发展,与城市化进程的加快,使得建筑业也取得了长足发展。然而相较于 其他行业,建筑业属于劳动密集型行业,且农民工在建筑业与社会经济的持续性发展中占据着重要社会地位。由于建 筑业的工作多数具有着脏、重、累、危险等特点,且农民工的合法权益,如工资发放等权益, 无法得到及时保证。这不仅 会影响到农民工的生活质量与水平,也容易影响到社会长治久安。为此,加强建筑业农民工权益保障问题的分析就显 得尤为重要。

[关键词] 建筑业; 农民工; 权益保障

\section{1 建筑业农民工权益保障问题分析的重要性}

1.1 有助于改善农民工的生活质量, 提升农民工工作 积极性

建筑业农民工权益保障问题多表现为工资拖欠、社 会保障体系不完善、农民工子女教育问题、法律维权意 识淡薄、农民工对工会了解少且人会率低等等。而有效 解决建筑业农民工权益保障问题, 将会提升建筑业农民 工自身的生活质量与生活水平, 同时也会让农民工在建 筑工作中变现地更加积极, 更加具有主人翁意识, 进而为 建筑业地持续性、快速、健康发展贡献自身力量。

1.2 有助于推动和谐社会构建工作地顺利进行

在我国和谐社会的构建工作中, 维护建筑业农民工 的合法权益是其中一项重要内容。然而, 相较于其他社会 群体, 在参与城市化建设过程中, 建筑业农民工仍然属于 弱势群体。而保护建筑业农民工的合法权益, 不仅可以有 效解决农民工面临的实际问题, 也有助于我国社会权益 保障体系的完善。同时,对于政府而言, 保护弱势群体中 的建筑业农民工权益, 才可以在构建和谐社会的过程中, 让他们更好的享受国家提供的公共服务, 以及促进社会 实现真正意义上的公平与正义。

1.3 有助于促进社会经济的持续性、快速、健康发展

建筑业农民工在社会经济发展中扮演着重要角色, 他们不仅可以促进我国社会经济的可持续性发展, 也可 以促进城乡区域经济间的统一协调发展。而通过进行建 筑业农民工权益保障问题分析, 可以有效地保障他们的 合法权益, 使得农村劳动力就业问题得到有效解决。另 外, 建筑业农民工在城市中的就业安置, 并不与城市人口 就业相冲突, 相反可以完善城市劳动力结构。国家政府通 过维护建筑业农民工的合法权益, 农民工可以将获得的 劳动收人带回家乡进行再创业, 这反而可以更好地促进 农业持续性发展, 实现城市反哺农村的经济发展政策。随 着农村劳动力向城市转移, 这在一定程度上也缓解了农
民工当地的就业安置压力。

\section{4 具有着深远的社会意义}

首先,通过进行建筑业农民工权益保障问题分析,有 助于快速实现我国社会结构转型, 促进城市化水平的进 一步提升。而对于农村来说,则可以促进农村改革的进一 步深化。其次, 有效解决建筑业农民工权益保障问题, 有 助于加强社会管理,促进社会的长治久安。再次,建筑业 农民工的权益得到保障, 有助于保障他们的基本生活, 甚 至于提升他们自身的物质生活水平。最后,建筑业农民工 权益保障问题得到解决, 还有助于减少上访现象的出现, 使得他们都能够认真得对待工作与生活, 并调动自身的 工作积极性, 为从属企业的持续性发展贡献自己的力量。

\section{2 建筑业农民工权益保障问题具体类型}

2.1 建筑业农民工劳动合同签约率有待进一步提高

建筑业农民工通过签订劳动合同, 将会使其自身的 合法权益得到法律有效维护。而当下的实际情况是,建筑 业农民工的劳动合同签约率有待进一步提高。这主要是 由以下原因造成:

首先,农民工自身的法律保护意识低,不懂的为自身 的合法权益做长远打算。甚至于认为,签约了劳动合同, 将会在很大程度上限制自身的利益, 比如, 当其违反规章 制度时, 会遭受到罚款等处罚, 或者离职时手续繁琐等 等。

其次,作为施工单位, 不按照法律规定与建筑业农民 工签约,在合同条款中过多的维护自身的利益,使得合同 内容不合法, 权利义务不对等。比如, 养老保险等社会保 障每月都在缴纳, 而农民工实际上却无法真正地享受到 此项权益。这使得农民工主动签订劳动合同的积极性大 大折扣。

最后,建筑单位合同签约意识有待进一步提高。由于 当下农民工过多, 有些建筑单位在招收农民工上具有着 随意性,也不愿意签署合同,来增加自身的经济负担。 
2.2 存在较为严重的工资拖欠现象

就当下的建筑业来看, 欠农民工工资的现象仍然屡 见不鲜。而造成这种现象的原因,大体可以分为以下几种 原因:

首先, 开发商原因。由于开发商出现了资金不足现 象,或者故意地延长工程结算,使得总承包单位没有足够 的资金支付给各分包单位，进而造成终端农民工的工资 得不到保障。

其次,建筑承建企业出现了供过于求的现象,使得当 下现有的建筑承建企业间的竞争力压力增大。为此,建筑 业主为了转移施工风险、降低施工成本、增加经济效益, 或者开发商在资金不足的情况下要求施工企业提前垫 资建设款。而施工企业为了获得建设权,接纳垫资建设建 议,并同意在工程施工完毕投人使用后方可获得工程款。 这就势必会造成建筑业农民工无法及时获得工资，进而 影响到农民工的生活水平与质量。

最后,施工单位为了赚取足够的经济效益,无视法律, 故意钻法律空子,在不与农民工签订劳动合同的前提下， 随意扣减农民工工资,使得农民工投诉事件屡屡发生。

2.3 建筑业农民工工会的人会率有待进一步提高

建筑业农民工工会是保障农民工合法权益的有效 组织。然而, 当下仍然有诸多的农民工未加人到工会组织 中。比如,些许施工单位聘请的农民工多是临时性的,流 动性比较大,在未签订劳动合同的前提下, 使得建筑企业 认为农民工没必要参加工会。或者,农民工没有真正的意 识到加人工会的重要性, 也缺少工会方面的知识, 使其自 身认为加不加人工会都无所谓。又或者,作为农民工工会 而言, 没有及时地向广大农民工宣传工会的重要性, 及时 在建筑业农民工合法权益遭受破坏时, 工会自身未真正 地维护建筑业农民工的合法权益。

\section{4 政府管理力度不够}

通过分析我国历年的数据统计可以看出: 当农民工 合法权益受到侵害时, 主动向政府相关部门寻求调解仲 裁的农民工比率非常小。而寻求调解仲裁的人员诉求多 数集中在工资拖欠、社会保险、工伤纠纷等问题上。而就 当下的解决成效来看, 政府还需要作出更大的努力。比 如,建筑业农民工在维权过程中,由于缺少编制和经费,使 得某些部门出现管理力度不够、服务不到位的现象。

2.5 社会保险涵盖面窄,且农民工无法实际享受到社 会保障

当下农民工无法真正地享受到社会保险相关权益 的具体表现如下:

首先,建筑农民工保险意识淡薄,无法真正地了解到 保险的重要性。

其次,建筑农民工的工作固定性差、且收人偏低,不 愿意将更多的资金投人到保险中。
文章类型: 论文 | 刊号( ISSN ):2705-0637(P)/2705-0645(O)

再次, 建筑企业为了减轻自身经济负担,不愿意为农 民工缴纳社会保险，通过额外资金补贴的方式劝说农民 工自动放弃缴纳社会保险,或者建筑单位自身躲避参保。

最后,社会保险在缴纳权限上有一定的时间限制, 而 对于农民工来说, 其自身工作具有不固定性, 难以较长时 间在一个单位或者城市工作, 使得其自身自愿缴纳社会 保险的积极性下降。

\section{3 我国建筑业农民工权益保障问题存在的宏观原因}

3.1 社会结构失衡造成城市农村间的利益分配不平 衡

为了促进社会经济的快速发展, 我国产业结构在不 断发生变化的过程中, 使得过多的农村富余劳动力越来 越多地向城市与非农业行业转移。这在一定程度上促进 了城市经济的发展。尽管如此, 我国工业化建设与农村经 济建设之间的结构分配仍然存在失衡, 使得国家的城市 化落后于工业化发展程度, 并造成农村富余劳动力无法 更好地从事非农业产业, 出现农村劳动力过剩现象。另 外, 农民工作为弱势群体, 当其自身的合法权益受到侵害 时, 政府未及时给予关注, 使得农民工权益未得到及时保 护, 进而使得各阶层的利益分化严重, 这也在很大程度上 影响到社会权益分配的公正性、公平性。

\section{2 社会保障体系有待进一步完善}

随着我国社会保险系统的不断完善,农民工的工伤保险、 医疗保险等得到了补充, 然而在养老、失业、失业保险上 仍然需要进一步完善。同时, 与城镇职工相比, 建筑业农 民工所享受到的社会福利仍然有限。

3.3 建筑业农民工权益保障制度监管有待进一步完 善

从我国当下的社会权益保障法规体系来看, 国家已 经出台了不少法律法规, 如《中华人民共和国劳动法》、 《违反和解除劳动合同的经济补偿办法》、《工资支付暂 行规定》、《工伤保险条例》等等, 都可以在很大程度上维 护建筑业农民工合法权益。然而, 在具体实施过程中, 由 于实施力度不大, 或者相应机关部门不作为, 使得建筑业 农民工权益保障受到侵害时, 无法及时获得保护。而作为 监管部门, 在监管建筑企业违规行为过程中, 给予的力度 不够,使得建筑企业尝到甜头后,而屡屡逃避社会责任。

3.4 地方政府在建筑业农民工方面的政策有待进一 步完善

尽管农民工的就业权具有一定的自由性, 但是由于 其自身不具备城市户口, 因此无法获得相应的就业保障 权、迁移权、教育权与社会保障权等等公民权利。同时, 由 于建筑业农民工群体大, 市政府各项职能与管理在满足 城市人口的同时, 无法更好得为农民工群体服务, 进而使 得建筑业农民工的权益与城市居民的权益不对等。也只 有地方政府不断地完善建筑业农民工方面的政策, 方可 
以有效保护农民工权益。

3.5 建筑业农民工的法律维权意识有待进一步提升

建筑业农民工的文化水平有限，甚至于在专业技能 上都有待进一步提高。因此, 多数的建筑业农民工只能从 事一些体力劳动或者较为简单的工作种类。建筑业农民 工在进行劳动的过程中, 学习法律意识或者维权意识的 主动性差, 使其自身权益遭受侵害时, 无法利用法律武器 充分地保护自身的合法权益, 甚至于只能选择一些非法 律手段来向建筑单位协商表达不满与争取权益。对于建 筑业聘用单位来说, 也正是利用农民工法律意识淡薄这 一特点, 才故意侵害农民工合法权益, 并时自身获得不正 当的利益。

\section{4 建筑业农民工权益保障问题解决措施}

4.1 完善建筑业农民工工资拖欠制度

随着我国社会经济的快速发展，越来越多的农村劳 动力加人到建筑业中。而为了有效规避建筑业农民工工 资拖欠问题, 则需要加强相应的制度建设, 从源头上对建 筑施工单位形成约束力。比如,山东省为了有效防止建筑 业农民工工资拖欠, 特别制定了以下制度: 建立欠款防范 约束制度、新型项目资金审查制度、在建项目资金审查 监控制度、建筑业劳务合同用工制度、建筑业劳务合同 用工制度、农民工工资按月发放制度、劳务工资保证金 制度、总承包负总责制度、规范带资承包制度、工程风险 管理机制。通过以上制度的实施,获得了良好成效。

4.2 建立监督审查制度,加大劳动合同签约率

对于建筑业农民工来说,其从事的工作具有脏、重、 累、危险等特征。因此,在工作过程中发生意外伤害的机 率要大很多。同时,由于当下用工市场存在着农民工供过 于求、建筑业拖欠工资现象频出的现状,使得农民工为了 有效保护自身的合法权益, 就需要主动与用工单位签订 劳动合同。而作为用工单位,也需要严格按照法律办事, 将建筑业农民工应享受的合法权益纸质化, 一旦发生劳 动纠纷, 无论是对企业来说, 还是对农民工来说, 都可以为 自身维权提供充足的法律依据。同时,作为国家政府, 需 要普及签订劳动合同的重要性, 并制定相应的监督检查 制度, 促进建筑业用工单位与农民工劳动合同签约率的 提升。

\section{3 进一步完善建筑业农民工权益保障制度}

只有不断地完善建筑业农民工权益保障制度，方可 以为维护建筑业农民工权益提供充足的法律支持。具体 完善建议可以分为以下几点: (1) 将建筑业农民工权益 保障政策与市场化资源配置相适应。在市场经济大环境 下，建筑业农民工权益保障也需要与国家经济发展间的 关系相协调。也只有这样, 方可以促进社会持续性、稳定 发展。(2)充分发挥政府各相关部门的协作联动作用。维 护建筑业农民工权益保障工作, 不是单个政府部门的职
责,而是需要各个相关政府部门共同协作。比如,劳动、总 工会、民政、卫生、食药监、建设、文化、司法、计生委等等 部门的协作运行。这样才可以全面的维护建筑业农民工 的权益保障。（3)完善相应制度，促进农民工完全融人到 城市中。由于农民工受到户口的限制, 使得农民工无法真 正的融人到城市中。为此, 国家可以与世界接轨, 实施户 口迁移登记制,从根本上改变人口迁移方式。另外,努力 实现农民工子女平等的人学教育权。

\section{4 要致力于解决建筑业农民工的基本需求}

解决建筑业农民工权益保障问题, 就需要从建筑业 农民工的基本需求人手。就当下的农民工需求来看,具体 的需求可以划分为以下几种:(1) 有效解决农民工工资 拖欠问题。(2)工伤医疗等社会保险需求。(3)提升工作 环境与居住环境质量。(4) 享受专业技能培训的需求。 (5)提升日常生活水平。(6)子女上学与自身养老问题。 在了解到以上基础需求后, 相关单位方可制定出相应的 解决对策,也才可以更好地维护社会稳定。

\section{5 要充分地发挥出政府自身的调控职能}

政府在建筑业农民工权益保障问题的解决中扮演 着重要角色。作为政府,需要将自身角色从参与者有效过 渡到调控者的身份。比如我国当下的建筑业农民工权益 保障问题,政府为了维护农民工的合法权益,往往政府会 作为牵头人来解决农民工工资纠纷, 或者政府通过组织 相应的职业技能培训,来满足农民工的学习需求。尽管作 为参与者起到了相应的效果, 但是效率并不是很高。为 此,政府应当从参与者的身份解脱出来,将身份转化为建 筑市场的调控者与权益保障政策的积极制定者。

\section{6 帮助农民工成功实现转型}

我国建筑行业已经获得了多年的持续性发展，城市 建筑业农民工数量逐步呈现富足状态, 因此,未来城市建 筑所需的农村劳动力总量会逐步下降。这就需要政府做 好相应政策调控,鼓励建筑业农民工及时做好转型,投人 到家乡建设中,或者转型到其他行业中。

\section{5 结束语}

总之,随着我国社会经济的快速发展,与城市化进程 的加快, 使得建筑业农民工需求量逐步增加。然而, 建筑 业农民工作为弱势群体，在从业过程中会遇到权益保障 问题。而这些问题得不到有效的解决,将会严重地影响到 社会经济的持续性发展与社会稳定。

\section{[参考文献]}

[1]刘鸣.城市建筑业农民工权益保障研究 [D].上 海:上海交通大学,2010:58.

[2]罗炜.建筑业农民工权益保障问题研究 [D].成都: 西南交通大学.2012:121.

[3]孙友然.SUNYOu-ran. 我国农民工权益保障问题 研究综述 [J].人口与社会,2008,24(2):26-31. 